\title{
Twig-Nesting Ants: The Hidden Predators of the Coffee Berry Borer in Chiapas, Mexico
}

\author{
Ashley Larsen ${ }^{1,3}$ and Stacy M. Philpott ${ }^{2}$ \\ ${ }^{1}$ Department of Ecology and Evolutionary Biology, 830 N. University, University of Michigan, Ann Arbor, MI 48195, U.S.A. \\ ${ }^{2}$ Department of Environmental Sciences, 2801 W. Bancroft St., Mail stop 604, University of Toledo, Toledo, OH 43606, U.S.A.
}

\begin{abstract}
Coffee is a globally important crop that is subject to numerous pest problems, many of which are partially controlled by predatory ants. Yet several studies have proposed that these ecosystem services may be reduced where agricultural systems are more intensively managed. Here we investigate the predatory ability of twignesting ants on the main pest of coffee, the coffee berry borer (Hypothenemus hampei) under different management systems in southwest Chiapas, Mexico. We conducted both laboratory and field experiments to examine which twig-nesting ant species, if any, can prey on free-living borers or can remove borers embedded in coffee fruits and whether the effects of the twig-nesting ant community differ with habitat type. Results indicate that several species of twig-nesting ants are effective predators of both free-living borers and those embedded in coffee fruits. In the lab, Pseudomyrmex ejectus, Pseudomyrmex simplex, and Pseudomyrmex PSW-53 effectively removed free-living and embedded borers. In the field, abundance, but not diversity, of twig-nesting ant colonies was influenced by shade management techniques, with the highest colony abundance present in the sites where shade trees were recently pruned. However, borer removal rates in the field were significant only in the shadiest site, but not in more intensively managed sites. This study provides evidence that twig-nesting ants can act as predators of the coffee berry borer and that the presence of twig-nesting ants may not be strongly linked to shade management intensity, as has been suggested for other arthropod predators of the borer.
\end{abstract}

Abstract in Spanish is available at http://www.blackwell-synergy.com/loi/btp

Key words: agroecosystem; biological control; Coffea arabica; Hypothenemus hampei.

COFFEE IS ONE OF THE MOST ECONOMICALLY IMPORTANT CROPS WORLDWIDE (Soto-Pinto et al. 2002). Like other globally cultivated crops, 'shade' coffee can be grown using a range of management systems, from cultivation under a thick, complex shade canopy with several tree species (traditional polyculture [TP]) to systems in which coffee is shaded by a few small trees all of the same species or of a few species (shade monoculture [SM]; Moguel \& Toledo 1999). Though shade level is only one of the factors influencing pest outbreaks (Beer et al. 1998), pruning shade trees has become a common prophylactic management technique for controlling high pest incidence. In the past few decades, a desire to increase yield has driven a trend to reduce over story shade and increase management intensity to minimize these pest outbreaks. Intensification, however, usually results in a lower diversity of predators, such as birds, bats and ants (Perfecto et al. 1996, 2004, 2007; Philpott et al. 2008a). Ironically for farmers, intensifying can thus sometimes necessitate a greater application of pesticides (Staver et al. 2001) to target certain pest species that were previously controlled by the predator community (Matson et al. 1997).

The most economically damaging coffee pest worldwide is the coffee berry borer (Hypothenemus hampei Ferrari) (Bustillo Pardey 2006, Jaramillo et al. 2006). This small scolytid beetle drills into the coffee berry and lays eggs inside the seed. It is generally believed that the berry borer prefers shade cover due to higher and more stable humidity levels (Damon 2000), but there remains no clear consensus (Beer et al. 1998). Bosselmann et al. (2009) found that incidence of borer-damaged berries was higher in shade plantations

Received 30 June 2009; revision accepted 2 September 2009.

${ }^{3}$ Corresponding author; e-mail: larsen.ashley@gmail.com while several other studies have found no effect of shade levels (Baker et al. 1989, Soto-Pinto et al. 2002).

Predatory ants function as important biological control agents in many agroecosystems (Risch \& Carroll 1982a, Way \& Khoo 1992, Perfecto \& Castañeiras 1998, Philpott \& Armbrecht 2006), and in some cases are believed to drive community dynamics (Risch \& Carroll 1982b). Numerous studies have found that ants reduce herbivores and herbivory (Rocha \& Bergallo 1992, Vandermeer et al. 2002, Philpott et al. 2008b) and that incidence of the coffee leaf miner, an important coffee pest, is inversely correlated with abundance of twig-nesting ants (De la Mora et al. 2008). Some species of ants affect the incidence of the coffee berry borer either by preventing them from boring in coffee fruits, or removing them once they are inside fruits. Since the adult borer takes about an hour to successfully enter the berry, ant predators have ample opportunity to catch the vulnerable beetle (Perfecto \& Vandermeer 2006). Predation on the borer has been reported for numerous species of ground nesting ants (Vélez et al. 2000, 2003; Bustillo et al. 2002; Varón 2002; Armbrecht \& Gallego 2007) and abundance of Azteca instabilis, a dominant canopy ant that often forages on coffee bushes, negatively correlates with fruits attacked by the borer (Perfecto \& Vandermeer 2006). Armbrecht and Gallego (2007) found ground-nesting ant predation on the borer to be significantly higher in shaded coffee farms than in sun plantations. Further, because $A$. instabilis constructs large carton nests on tree trunks and branches, the abundance of $A$. instabilis colonies is positively influenced by large trees (Philpott 2006), indicating that their predatory impacts may be more important in farms with a more complex shade canopy. Impacts of both ground-nesting ants and $A$. instabilis, however, are spatially limited. Azteca instabilis nests are 
generally in the lower reaches of the canopy, and ground-nesting ants are on the ground. Even though both of these groups of ants frequently forage on coffee plants, their nests are located in other substrates within coffee farms. In contrast, twig-nesting ants, in addition to nesting in hollow branches on shade trees, often occupy hollow twigs on coffee bushes, a proximity that may enable more frequent and more abundant foraging on prey items existing on the coffee bushes themselves. Furthermore, nest site availability and diversity in terms of coffee twig size and diameter are likely similar, regardless of management practices. Therefore, there is the potential for twig-nester occupancy and foraging on a large percentage of coffee in all management systems. Despite this, no studies have examined the potential predatory function of twig-nesting ants in controlling the coffee berry borer. We were interested in determining the predation potential of twig-nesting ants on the berry borer and whether there is a difference in predation under different management techniques. Using both laboratory and field experiments, we asked the following: (1) Do rates of coffee berry borer infestation vary with differences in shade management? (2) Do twig-nesting ant species remove free-living coffee berry borers or borers embedded in fruits, and which, if any, of the common twig-nesting ant species are the most effective predators? (3) Does removal of berry borers by twig-nesting ants differ depending on shade management? and (4) Do any observed differences in removal rates resulting from management correlate with changes in abundance or richness of twig-nesting ants?

\section{METHODS}

STUDY SITE.-We conducted the study during June and July 2008 on two adjacent coffee farms located in the Soconusco region of Chiapas, Mexico. The sites are situated at $900-1150 \mathrm{~m}$ asl and receive an average of $c a 4500 \mathrm{~mm}$ of rainfall annually. Finca Hamburgo $\left(15^{\circ} 10^{\prime} \mathrm{N}, 92^{\circ} 19^{\prime} \mathrm{W}\right)$, is a conventional SM coffee farm that is managed with agrochemicals. The neighboring farm, Finca Irlanda $\left(15^{\circ} 11^{\prime} \mathrm{N}, 92^{\circ} 20^{\prime} \mathrm{W}\right)$, is an organic shade farm that, due to recent management interventions, now contains several management types. Traditionally, the farm was managed as a commercial polyculture (CP), and some areas remain under this management. In May-June of 2007 and 2008, shade trees in certain sections of the farm were heavily pruned, creating some areas more like a SM in different stages of regeneration (Cut 07, Cut 08, respectively). In addition, Irlanda contains a small, minimally managed TP area with a mostly closed canopy of second growth, planted forest (Moguel \& Toledo 1999). Field experiments took place in each of these five habitat types, from highest to lowest shade cover: TP, CP, Cut 07, Cut 08, and SM. All coffee management systems listed here follow vegetation characteristics as described in Philpott et al. (2008a). In each management type, we established transects along trails in areas representative of the management, and marked one coffee bush every $50 \mathrm{~m}(\mathrm{~N}: \mathrm{TP}=13, \mathrm{CP}=14$, Cut $07=15$, Cut $08=14, \mathrm{SM}=16$ bushes).

To examine the background rates of berry borer infestation on coffee fruits in different habitat types, we estimated the percentage of damaged berries per bush by counting the number of damaged and undamaged berries on three branches at breast height on all marked bushes. Additionally, we counted the number of coffee seedlings within a $1-\mathrm{m}$ radius of the focal plant as a proxy of number of unharvested berries from the previous year. Unharvested berries are important sources for borer propagation and function as both a breeding site and overwintering habitat during the interharvest season when berries are no longer readily available (Armbrecht $\&$ Gallego 2007). We compared the mean percentage of damaged berries in different habitats using a univariate ANOVA and a Tukey's test for post hoc comparisons to distinguish significant differences between habitats.

Then, using the same coffee bushes, we set up an experiment to examine for possible correlations between twig-nesting ant richness, identity, abundance and borer removal from infested berries. We collected unripe coffee fruits with visible borer holes in one area of the coffee farm (under CP management) and fruits were randomly assigned to either experimental or control bags. The experimental bags were made of mesh with $3 \times 3 \mathrm{~mm}$ holes and the control bags were made of extremely fine polyester mesh with $76+$ holes $/ \mathrm{cm}^{2}$. Borers and most ant species at the study site could easily move in and out of the experimental bags, however, no borers or ants could move in or out of the fine mesh control bags. On every marked coffee bush we placed one experimental and one control bag, each containing 10 borer-damaged fruits. Bags were attached to two branches at breast height using twine. We collected bags and berries after $15 \mathrm{~d}$. We cut open all berries and counted the total number of borers in the berries and free in the bags. We noted presence or absence of ants in the bags and collected and identified all ants present. We compared the mean number of borers per bag in experimental and control bags with a univariate ANOVA, with mesh type and habitat type as main factors. We used Tukey's tests for post hoc comparisons to distinguish significant differences between habitats.

To examine the ant assemblages on plants where we placed bags, we conducted a 3-min visual survey on every marked coffee bush. Visual surveys included shaking the plant and visually scanning leaves, branches, the trunk, and berries. Additionally, we snapped off and opened all dry twigs on each coffee plant to examine the number of hollow twigs, the number of twigs containing ant colonies, and to identify the species of nesting ants. We defined a 'twig-nesting' ant species as a species found occupying hollow coffee twigs, a categorization unrelated to nesting ability in other substrate such as on trees or in the ground. We defined 'colonies' as twig-nests containing ants and brood. We examined ant communities based on total number of occupied twigs, number of species, the Shannon diversity index, $H$, and species evenness, $E$.

LABORATORY EXPERIMENTS.-We conducted laboratory experiments to assess whether three specific species of twig-nesting ants can predate both free-living (outside coffee berries) and embedded (inside berries) borers. We collected coffee twigs containing ant colonies of the species Pseudomyrmex ejectus F. Smith, P. simplex F. Smith, and $P$. PSW-53 in the field and placed them in plastic containers. These species were chosen because they are among the most common twig-nesting species in the study sites (Philpott \& Foster 2005). A fourth, common species, Procryptocerus hylaeus Kempf, was not 
included because it was difficult to maintain under laboratory conditions. We fed ants honey as necessary to maintain colonies, but starved colonies for at least $24 \mathrm{~h}$ before the start of experiments. We obtained free-living borers by collecting unripe coffee berries with visible borer holes and cutting them open to remove borers. We randomly assigned five free-living borers to a plastic box with a twig-colony. After $24 \mathrm{~h}$, we noted the number of missing and dead borers inside each container. Missing borers were presumably taken inside of the twig nests, as escape from boxes was not possible. We analyzed differences in the number of dead and missing borers in boxes with each species using a one-sample $t$-test with 0 as the test value. To examine ant impacts on embedded borers, we randomly assigned five berries with visible borer holes to a container with one of the three ant species, or a control container without a twig-colony. At the end of $24 \mathrm{~h}$, we opened all berries and counted the number of recovered borers. We compared the number of borers recovered among species treatments and the control with univariate ANOVA and a Tukey test for post hoc comparisons. All statistical tests were conducted using SPSS v. 10.

\section{RESULTS}

FIELD EXPERIMENT.-Background rates of fruits with berry borer damage ranged from $>35$ percent to $<5$ percent in the different management types. There were a significantly greater number of fruits with borer damage in the TP farm compared with all other managed systems, while CP, Cut 07 and Cut 08 had similar proportions of damaged fruits, despite differences in management technique. SM had the least damage, though it did not differ significantly from damage levels in the two recently cut regions (Fig. 1A). The average number of coffee seedlings within a $1-\mathrm{m}$ radius of the focal plants reflected the trend in damage levels among management types (Fig. 1B). At the level of management system, the mean proportion of damaged fruits was positively correlated with mean number of coffee seedlings $\left(R^{2}=0.955, P=0.004\right)$.

Field removal rates, as evaluated by the difference between the number of berries with borers in experimental bags (with predators) compared with control bags (without predators), were highest in the TP. The TP experimental bags averaged almost half as many recovered borers as control bags (Table 1) and no significant difference was found between experimental and control bags in the other management types (Table 1).

We recovered 35 species of ants, eight of which were found in twig-nests. We found at least one species of ant (twig-nesting, arboreal and ground-nesting) on 71 of the 76 bushes surveyed. Occupation by twig-nesting ants varied by system, with the recently cut areas having the greatest percentage of bushes with at least one colony (Cut $07=82 \%$; Cut $08=80 \%$ ) and the undisturbed areas having similar levels of occupancy $(\mathrm{TP}=50 \%$; $\mathrm{CP}=60 \% ; \mathrm{SM}=41 \%)$. Of the eight twig-nesting species encountered, the most abundant twig-nesting species was $P$. ejectus, followed by $P$. hylaeus, P. simplex and P. PSW-53. These four species comprised $73 \%$ of twig-nesting species encountered. The numbers of species found, and the diversity and evenness of twignesting ants was similar in each habitat type (Table 2). Diversity
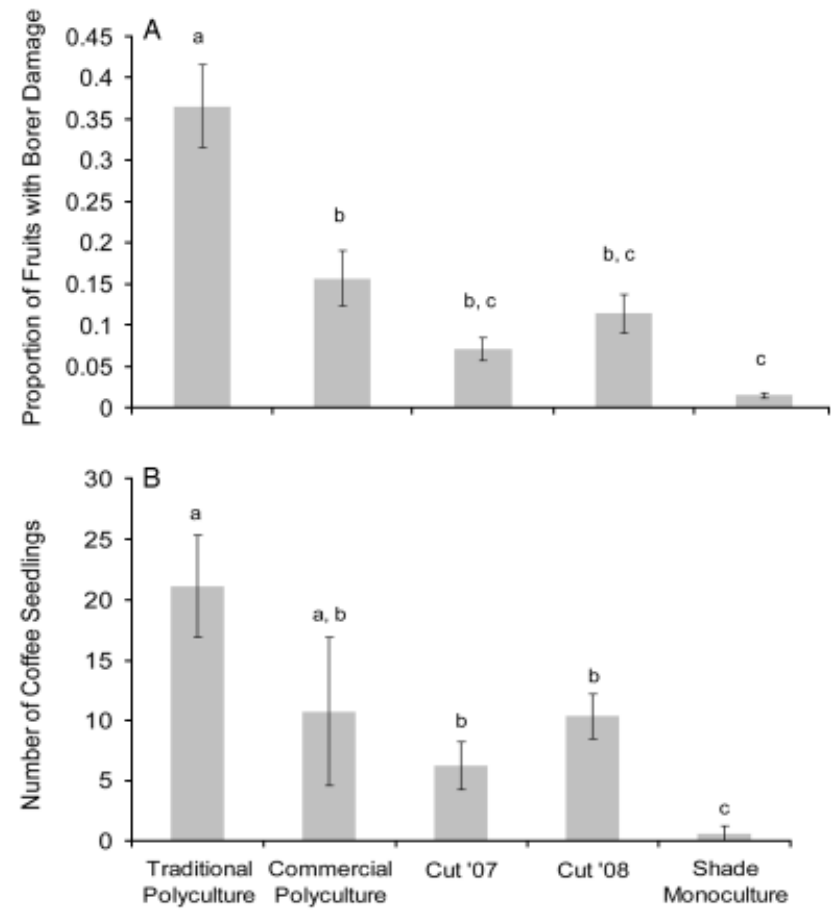

FIGURE 1. (A) Proportion of coffee fruits with visible borer damage in different management systems. The proportion of damaged fruit negatively corresponded to management intensity with the highest proportion of damaged fruit in the shadiest site, lowest proportion of damaged fruit in the least shady site and intermediate levels of damaged fruit in the sites with shade levels between traditional polyculture and shade monoculture. (B) The average number of coffee seedlings within a $1-\mathrm{m}$ radius of experimental bushes. Number of coffee seedlings is used as a proxy for the number of unharvested berries from previous season. Unharvested berries are considered a critical habitat for borers when few berries are available, and have been correlated with infestation levels in the following season. This trend is reflected in (A).

at the site level did not explain field removal rates of berry borers (Fig. 2).

Laboratory experiment.-In laboratory experiments, $P$. ejectus, $P$. simplex, P. PSW-53 killed some free-living borers, as we recovered

TABLE 1. Field recovery rate of embedded borers. Field recovery rate, the difference in number of recovered borers between control bags and experimental bags, was significant for the traditional polyculture, the shadiest site in the study, but was not significant for all other sites. $\mathrm{N}$ is the number of coffee bushes in each system. Each bush had one control and one experimental bag containing ten borer-damaged berries.

\begin{tabular}{lcccr}
\hline System & Control & With predators & $N$ & \multicolumn{1}{c}{$P$} \\
\hline Traditional polyculture & $8.46 \pm 0.65$ & $4.23 \pm 0.33$ & 13 & $<0.001$ \\
Shade polyculture & $8.21 \pm 0.59$ & $6.57 \pm 0.47$ & 14 & 0.597 \\
Cut 07 & $7.40 \pm 0.49$ & $6.20 \pm 0.41$ & 15 & 0.736 \\
Cut 08 & $5.71 \pm 0.41$ & $4.86 \pm 0.35$ & 14 & 0.997 \\
Shade monoculture & $6.94 \pm 0.43$ & $5.00 \pm 0.31$ & 16 & 0.310 \\
\hline
\end{tabular}


TABLE 2. Shannon's diversity index $(\mathrm{H})$ and Evenness index $\left(\mathrm{E}_{h}\right)$. Diversity and evenness of twig-nesting ants were similar in all sites despite differences in management practices. Numbers indicate the proportion of colonies represented by a given ant species.

\begin{tabular}{|c|c|c|c|c|c|}
\hline Ant species & Traditional polyculture & Shade polyculture & Cut 07 & Cut 08 & Shade monoculture \\
\hline Camponotus sp.1 & 0.273 & 0 & 0 & 0.048 & 0.043 \\
\hline Nesomyrmex echinatinodis & 0 & 0.105 & 0.0811 & 0.095 & 0.130 \\
\hline Procryptocerus hylaeus & 0.182 & 0.263 & 0.2162 & 0.381 & 0.087 \\
\hline Pseudomyrmex simplex & 0.455 & 0.105 & 0.0811 & 0.238 & 0.087 \\
\hline Twig-nesting ant richness & 4 & 5 & 5 & 7 & 6 \\
\hline Shannon’s DI $(H)$ & 1.24 & 1.49 & 1.36 & 1.67 & 1.43 \\
\hline Evenness $E_{\mathrm{h}}$ & 0.517 & 0.504 & 0.377 & 0.549 & 0.457 \\
\hline Total ant richness & 15 & 17 & 17 & 20 & 14 \\
\hline
\end{tabular}

borer parts after the $24 \mathrm{~h}$ experimental period. Additionally, $P$. PSW-53 was observed carrying borers to the twig-nest. All three ant species removed a significant number free-living borers (P. ejectus, $P<0.001 ; \quad P$. simplex, $P=0.002 ; \quad P$. PSW-53 $P<0.001)$. Pseudomrymex PSW-53 was the most effective predator, removing an average of $2.43 \pm 0.48$ of the five original borers in the $24 \mathrm{~h}$ period. Pseudomyrmex ejectus and $P$. simplex removed an average of $1.53 \pm 0.24$ and $1.36 \pm 0.28$ borers, respectively.

In the experiment with embedded borers, we recovered on average $2.88 \pm 0.04,2.82 \pm 0.33$, and $2.27 \pm 0.34$ whole borers (alive and dead) in containers with $P$. ejectus, $P$. simplex and $P$. PSW-53 respectively. In control containers, we recovered on average $4.17 \pm 0.32$ borers, a significantly higher number than for each of the three ant species tested ( $P$. ejectus, $P<0.05$; $P$. simplex, $P<0.05 ;$ P. PSW-53 $P<0.01$, respectively).

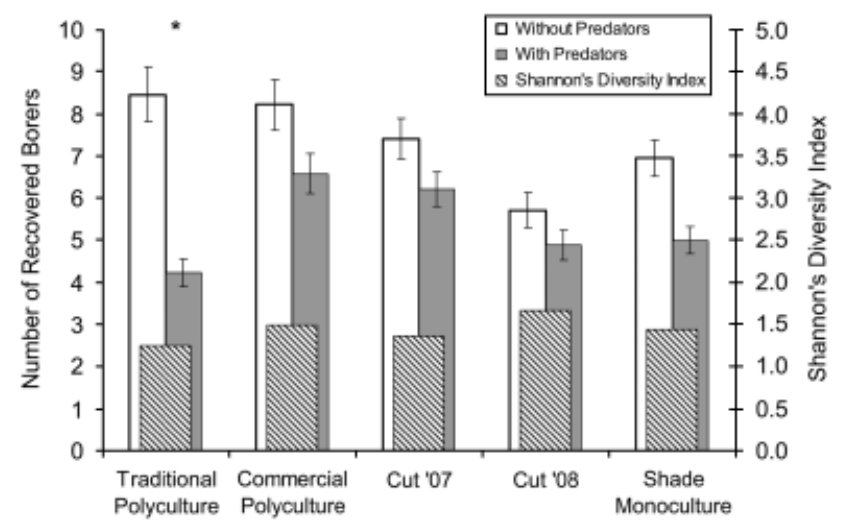

FIGURE 2. Field predation on berry borers was significant only in the traditional polyculture while diversity of ants did not vary appreciably on a site level. Variation in predation but not in diversity indicates something other than twignesting ant diversity is probably accountable for the observed differences in borer removal.

\section{DISCUSSION}

These results are the first to show that twig-nesting ants are effective predators of the coffee berry borer located both outside of and embedded within coffee fruits. Predation on the berry borer has been widely documented for ground-nesting and canopy dominant ants. Armbrecht \& Gallego (2007) found ground-nesting ants effectively predated on free borer adults, and Vélez et al. (2001) recorded ant predation on all life stages of the borer. Perfecto \& Vandermeer (2006) found that the abundance of borer-attacked fruits on coffee plants negatively correlated with the presence of scale insects (Coccus viridis); these scales are heavily dependent on a dominant canopy ant, Azteca instabilis, for survival. They inferred that the negative relationship was due to Azteca limitation of borer activity (Perfecto \& Vandermeer 2006). Despite the rather large literature on ant predation in general and on $H$. hampei specifically, this is the first study to document borer predation by twig-nesting ants. Twignesting ants have easy access to berry borers because these ants, in addition to occupying shade trees, nest and forage on coffee plants. Additionally, as twig-nesting ants can also follow borers into borer holes, these ants have access to the longest stage of the borer lifecycle, thus providing a biological control advantage over larger ant species (Armbrecht \& Gallego 2007). In the laboratory experiments, Pseudomyrmex ejectus, P. simplex, and P. PSW-53, all common species in the farms, were able to predate on both free-living and embedded adult borers.

Field results show the percentage of damaged berries was highest in the least managed farm habitat, intermediate in the intermediately managed areas and lowest in the most intensely managed area, which is somewhat surprising given previous results of the impact of ant predators on berry borers (Baker et al. 1989; Vélez et al. 2000, 2001, 2003; Perfecto \& Vandermeer 2006; Armbrecht \& Gallego 2007). We also found that the number of coffee seedlings (a measure of unharvested fruits) declined with decreasing shade. It is well documented that adult borers both oviposit and overwinter 
in unharvested and fallen berries, and that the following year's infestation level is strongly influenced by the overwintering population (Damon 2000). Therefore, we cannot determine if high damage levels in the shadiest management area are a result of borer preference to management technique or reflective of the care with which last season's berries were harvested. Additionally, due to the probable application of pesticides in the conventional farm, the level of damaged fruits in the SM may be artificially low.

In the field experiment, we found that borer disappearance from mesh bags differed from control bags only in the shadiest site, but not in any of the sites with greater management intensity. Our sampling data of one predator group, twig-nesting ants, indicate that richness and diversity were similar in the habitats examined, despite differences in management practices. Therefore, it is likely borer removal is heavily influenced by factors other than twig-nesting ants. The observed differences in removal rates may be due to differences in diversity or abundance of berry borer predators as a whole. Although most other studies have documented a decreased diversity of ground-nesting ant (e.g., Philpott \& Armbrecht 2006) and vertebrate predators (Perfecto et al. 1996, 2004; Kellermann et al. 2008), some predatory arthropods, such as spiders, are more diverse in more intensive farms (Pinkus-Rendon et al. 2006). Because twig-nesting ants inhabit coffee twigs attached to the plant, and that habitat exists in plants growing in both shade and sun plantations, it appears twig-nesting diversity is less affected by shade levels.

Differences in removal rates in different habitats might also be related to presence of alternative prey resources for ants, or other complex trophic interactions. Alternative food resources may include other arthropods, honeydew producing hemipterans or even borers in the process of drilling that are easier to predate than those already in the berry (as in the experiment). Additionally, a less biodiverse ant and arthropod community as a result of intensification may reduce intraguild competition for prey resources, thereby making embedded borers a less desirable prey option in intensified farms. However, for practical reasons, the ability to penetrate and remove borers is of importance, even if it is less common during times of plenty. Infested berries that are missed during the harvest serve as a source population of borers until the following year's fruit becomes available (Baker \& Barrera 1993). During this period of decreased prey abundance, predation by twig-nesting ants may help control the borer infestation.

This study highlights the predation potential of twig-nesting ants on the coffee berry borer, both free-living and for those already within the fruit. Our data demonstrate that predation on the borer was only significant in the TP, the site which also had the highest borer infestation. Since richness, evenness and diversity of twignesters were similar across several management types, this strongly implies that the population density of the borer is driven by factors other than twig-nesting ant predation. One potentially important correlate to borer infestation is the presence of residual berries on the ground, while increased predation likely reflects the synergistic effect of other small arthropod predators present in the less intensively managed zone. Though laboratory results clearly show that twig-nesting ants prey on the berry borer, the complexity of the food web in the field makes the level of predation difficult to determine. Further investigation and experimentation is needed to both more clearly determine the responsible mechanisms causing differences in predation and to evaluate the scale at which twig-nesting ants predate the coffee berry borer.

\section{ACKNOWLEDGMENTS}

We thank G. Domínguez, B. Chilel, and A. De la Mora who provided assistance in the field. G. Ibarra-Nuñez from ECOSUR Tapachula provided logistical support. We thank H. Liere, D. Jackson, A. MacDonald and J. Vandermeer, I. Perfecto, N. Bluthgen, and two anonymous reviewers for providing useful comments on the manuscript. Funding was provided by the University of Toledo, a NSF DEB-0349388 award to I. Perfecto and J. Vandermeer and the John P. Kennedy Research Award, University of Michigan to AL.

\section{LITERATURE CITED}

ARmbrecht, I., AND M. C. Gallego. 2007. Testing ant predation on the coffee berry borer in shaded and sun coffee plantations in Colombia. Entomol. Exp. Appl. 124: 261-267.

BAKER, P. S., AND J. F. BARRERA. 1993. A field study of a population of coffee berry borer, Hypothenemus hampei (Coleoptera; Scolytidae), in Chiapas, Mexico. Trop. Agric. 70: 351-355.

Baker, P. S., J. F. Barrera, and J. E. Valenzuela. 1989. The distribution of the coffee berry borer (Hypothenemus hampei), in southern Mexico: a survey for a biocontrol project. Trop. Pest Manage. 35: 163-168.

Beer, J., R. Muschler, D. Kass, and E. Somarriba. 1998. Shade management in coffee and cacao plantations. Agroforestry Sys. 38: 139-164.

Bosselmann, A. S., K. Dons, T. Oberthur, C. S. Olsen, A. Raebild, and H. Usma. 2009. The influence of shade trees on coffee quality in small holder coffee agroforestry systems in Southern Colombia. Agric. Ecosyst. Environ. 129: 253-260.

Bustillo, A. E., R. Cardenas, and F. J. Posada. 2002. Natural enemies and competitors of Hypothenemus hampei (Ferrari) (Coleoptera: Scolytidae) in Colombia. Neotrop. Entomol. 31: 635-639.

Bustillo Pardey, A. E. 2006. A review of the coffee berry borer Hypothenemus hanmpei (Coleoptera: Curculionidae: Scolytinae), in Colombia. Rev. Soc. Colombiana Entomol. 32: 101-116.

Damon, A. 2000. A review of the biology and control of the coffee berry borer, Hypothenemus hampei (Coleoptera: Scolytidae). Bull. Entomol. Res. 90: 453-465.

De la Mora, A., G. Livingston, and S. M. Рhilpott. 2008. Arboreal ant abundance and leaf miner damage in coffee agroecosystems in Mexico. Biotropica 40: 742-746.

Jaramillo, J., C. Borgemeister, and P. Baker. 2006. Coffee berry borer Hypothenemus hanmpei (Coleoptera: Curculionidae): searching for sustainable control strategies. Bull. Entomol. Res 96: 223-233.

Kellermann, J. L., M. D. Johnson, A. M. Stercho, and S. C. Hackett. 2008. Ecological and economic services provided by birds on Jamaican Blue Mountain Coffee Farms. Conserv. Biol. 22: 1177-1185.

Matson, P. A., W. J. Parton, A. G. Power, and M. J. Swift. 1997. Agricultural intensification and ecosystem properties. Science 277: 504-509.

Moguel, P., AND V. M. Toledo. 1999. Biodiversity conservation in traditional coffee systems of Mexico. Conserv. Biol. 13: 11-21.

Perfecto, I., I. Armbrecht, S. M. Philpott, L. Soto-Pinto, and T. V. DiETSCH. 2007. Shaded coffee and the stability of rainforest margins in northern Latin America. In T. Tscharntke, C. Leuschner, A. Zeller, 
E. Guhadja, and A. Bidin (Eds.). The stability of tropical rainforest margins, linking ecological, economic and social constraints of land use and conservation, pp. 227-263. Springer, New York, New York.

Perfecto, I., AND A. CastañEIras. 1998. Deployment of the predaceous ant and their conservation in agroecosystems. In P. Barbosa (Ed.). Perspectives on the conservation of natural enemies of pest species, pp. 269-289. Academic Press, San Diego, California.

Perfecto, I., R. A. Rice, R. Greenberg, and M. E. Van der Voort. 1996. Shade coffee: A disappearing refuge for biodiversity. Bioscience 46: 598-599.

Perfecto, I., and J. Vandermeer. 2006. The effect of an ant-hemipteran mutualism on the coffee berry borer (Hypothenemus hampei) in southern Mexico. Agric., Ecosyst. Environ. 117: 218-221.

Perfecto, I., J. H. Vandermeer, G. L. Bautista, G. I. Nuñez, R. GreenberG, P. BICHIER, AND S. LANGRIDGE. 2004. Greater predation in shaded coffee farms: The role of resident neotropical birds. Ecology 85: 2677-2681.

PнiLPotT, S.M. 2006. Ant patchiness: A spatially quantitative test in coffee agroecosystems. Naturwissenschaften 93: 386-392.

Philpott, S. M., W. J. Arendt, I. Armbrecht, P. Bichier, T. V. Diestch, C. Gordon, R. Greenberg, I. Perfecto, R. Reynoso-Santos, L. SotoPinto, C. Tejeda-Cruz, G. Williams-Linera, J. Valenzuela, and J. M. Zolotoff. 2008a. Biodiversity loss in Latin American coffee landscapes: Review of the evidence on ants, birds, and trees. Conserv. Biol. 22: 1093-1105.

Philpott, S. M., AND I. ARmbReCht. 2006. Biodiversity in tropical agroforests and the ecological role of ants and ant diversity in predatory function. Ecol. Entomol. 31: 369-377.

Philpott, S. M., AND P. F. Foster. 2005. Nest-site limitation in coffee agroecosystems: Artificial nests maintain diversity of arboreal ants. Ecol. Appl. 15: 1478-1485.

Philpott, S. M., I. Perfecto, and J. Vandermeer. 2008b. Behavioral diversity of predatory arboreal ants in coffee agroecosystems. Environ. Entomol. 37: 181-191.

Pinkus-Rendon, M. A., G. Ibarra-Nuñez, V. Parra-Tabla, J. A. Garcia-BallInAS, and Y. Henaut. 2006. Spider diversity in coffee plantations with different management in Southeast Mexico. J. Arachnol. 34: 104-112.
Risch, S. J., AND C. R. CARROLL. 1982a. The ecological role of ants in two Mexican agroecosystems. Oecologia 55: 114-119.

Risch, S. J., AND C. R. CARROLl. 1982b. Effect of a keystone predaceous ant, Solenopsis geminata, on arthropods in a tropical agroecosystem. Ecology 63: 1979-1983.

Rocha, C. F., AND H. G. Bergallo. 1992. Bigger ant colonies reduce herbivory and herbivore residence time on leaves of an ant-plant Azteca mulleri vs. Coleomero ruficornis on Cecropia pachystachya. Oecologia 91: 249-252.

Soto-Pinto, L., I. Perfecto, and J. Caballero-Nieto. 2002. Shade over coffee: Its effects on berry borer, leaf rust and spontaneous herbs in Chiapas, Mexico. Agroforestry Sys. 55: 37-45.

Staver, C., F. Guharay, D. Monterroso, and R. G. Muschler. 2001. Designing pest-suppressive multistrata perennial crop systems: Shadegrown coffee in Central America. Agroforestry Sys. 53: 151-170.

Vandermeer, J. H., I. Perfecto, G. Ibarra-Nuñez, S. Phillpott, and A. GarCIA Ballinas. 2002. Ants (Azteca sp.) as potential biological control agents in shade coffee production in Chiapas, Mexico: Complication of indirect effects. Agroforestry Sys. 56: 271-276.

VARÓN, E. H. 2002. Distribución espacio-temporal de hormigas con potencial como depredadoras de Hypothenemus hampei e Hypsipyla grandella, en sistemas agroforestales de café, en Costa Rica. PhD Dissertation, Catie, Turrialba, Costa Rica.

Vélez, M., A. E. Bustillo, and F. J. Posada. 2000. Predación sobre Hypothenemus hampei, (Ferrari) de las hormigas Solenopsis spp., Pheidole spp. y Dorymyrmex spp. durante el secado del café. In S. C. d. Entomología (Ed.). Resumenes XXVII Congreso Medellín, Colombia.

Vélez, M., A. E. Bustillo, and F. J. Posada. 2001. Hormigas de la zona central cafetera y perspectivas de su uso en el control de Hypothenemus hampei (Ferrari) (Coleoptera: Scolytidae). In S. C. d. Entomología (Ed.). Resúmenes XXVIII Congreso Pereira, Colombia.

Vélez, M., A. E. Bustillo, and F. J. Posada. 2003. Depredación de Hypothenemus hampei por Solenopsis geminata y Gnamptogenys sp. (Hymenoptera: Formicidae). In S. C. d. Entomología (Ed.). Libro de Resúmenes XXX Congreso Universidad Autonoma, Cali, Colombia.

Way, M. J., AND K. C. KHOO. 1992. Role of ants in pest management. Annu. Rev. Entomol. 37: 479-503. 